\title{
FELLOW CITIZENS OR ALIENS? GALICIAN REFUGEES DURING THE FIRST WORLD WAR IN HUNGARY
}

\author{
Kamil Ruszała \\ http://orcid.org/0000-0002-6143-107X
}

Jagiellonian University in Kraków

\begin{abstract}
The outbreak of the First World War (1914-1918) forced the countless civilians to leave their homes and to become war refugees. This topic has remained largely unexplored by the historians. The number of refugees from the multinational Galicia in the years 1914-1918 was large in many parts of the former Austria-Hungary, which finds its reflection in archival materials scattered over various archives and over an extensive territory. This paper presents the issue of the Galician war refugees who found themselves in the Lands of the Crown of Saint Stephen. It also outlines the general problem of emigration as well as describes relations between the refugees and the local people. It was not only due to antagonisms but also due to the administrative decisions of the Hungarian authorities that the Galician refugees remained alien to the locals, despite the fact they all were citizens of the same Habsburg Monarchy.
\end{abstract}

Keywords: First World War, refugees, Galicia, Austria-Hungary.

\section{INTRODUCTION}

There were different reactions among the Galicians to the beginning of the FWW, and different attitudes. On the one hand, some of them were overcome by panic. Some were evacuated by the national authorities, particularly from the towns and cities of military significance (vide Lviv, Przemyśl, Cracow) or simply from bigger towns and cities of Galicia. Others remained in their homes, exposed to war atrocities in their hometowns and villages.

There were different directions of escape or evacuation for the civilians from Galicia (Poles, Jews and Ukrainians, who used to be called Ruthenians still at the beginning of the war). Geographically speaking, they ended up in Austria as far as 
Vorarlberg, i.e. at the border with the neutral Switzerland, gathering mainly in Lower Austria (apart from Vienna, also in the several major refugee camps, like Gmünd, Hollabrunn, Brück an der Leitha and others), Upper Austria, Styria (the camp in Wagna near Leibnitz, St. Michael, Graz and other districts in the north and south of the land), Carinthia (the camp in Wolfsberg). A large number of refugees landed in Bohemia, where they were accommodated in over three thousand districts and refugee camps (Choceň, Havlíčkův Brod, etc.) and in Moravia, where they also found accommodation in many towns and barrack camps, mainly for Galician and (fewer) Bukovinian Jews (Mikulov, Kyjov, Pohořelice and others). Refugees also reached Alpine states (Salzburg, Tyrol, Vorarlberg), Carniola and the Austrian Littoral. Many people ended up south of Galicia, i.e. within the Lands of the Crown of Saint Stephen. The Galicians who stayed there during the war were those who in 1914 had spontaneously fled the ravages of war and, to a lesser extent, joined organized evacuation. It was only the later changes on the Galician front that generated further masses of refugees (the Brusilov Offensive in June 1916).

\section{IN HUNGARY}

Escaping the oncoming enemy onslaught across the southern border of the crown land seemed a safe move to Galicians. However, right from the start the refugees met with the first restriction: they had to prove they would be able to support themselves, which had to be confirmed by the admitting authority. ${ }^{1}$ This is what it looked like on paper, but it is hard to say whether such verification actually took place there and then. Thorough control of people's movements was not fully possible, hence arbitrary relocations. At the start of September, Budapest press wrote that day by day more and more refugees were landing in Hungarian towns and cities. It was quite common to see peasants leading their livestock or Galician women carrying domestic appliances. The Hungarian press cited Debrecen as a city of refugees (menekültek városa), where a large group of them found shelter in the early autumn of 1914. During the quartering they were divided into three groups. The richer could live where they wanted, which meant that they could take a room in a hotel or find an apartment on their own. The second group was office workers and the third one - poorer people for whom accommodation was found in Szatmár near Debrecen. Some of the exiles tried to show their gratitude, which they did by saying perhaps the only learned word - köszönöm. ${ }^{2}$ The feeling of almost complete alienation, the language barrier, unfriendliness and widespread poverty, all contributed to Galician refugees feeling ill-at-ease in Hungary right from the start and unwelcome by a substantial majority of Hungarians.

1 Österreichisches Staatsarchiv (in the following: ÖStA), Kriegsarchiv (in the following: KA), Zentralstelle, Kriegsministerium, HR, Abt. 10, Karton (in the following: Kt.) 516, Zl. 1914/10/A.10 2/24-2.

2 Budapesti Hirlap 1914, no. 224, September 13, pp. 8-9. 
A lot of refugees reached Budapest; it can be estimated that out of 100,000 refugees who landed in Hungary, as many as $30 \%$ stayed in the capital. ${ }^{3}$ Also in Budapest, there were attempts to limit the influx, particularly of the poorer ones. As early as on October 7, 1914, it was announced that the main meeting point for the refugees with nothing to live on, would be Szatmárnémeti (present day Satu Mare in Romania). From there they were going to be sent straight to an inspection point in Uherské Hradiště. ${ }^{4}$ The Hungarian Minister for Internal Affairs explained that on October 5, the military authorities had ordered to remove civilians from the Máramaros County in 48 hours. The problem concerned not only the refugees from Galicia and Bukovina, but also indigenous Hungarians. The minister explained the decision, arguing that a lot of refugees were left with nothing to live on and some of them did not want to remain in a strange country any longer. Thus, sending them to Moravia was justified. ${ }^{5}$ The financial situation of Hungary was not good enough to take proper care of the refugees. At the end of November 1914, a group of 120 refugees who had landed in Oradea sent a telegram to the minister for internal affairs, which said that so far they had lived with the help of the local people but it was not possible any more, as everyone was getting increasingly poor, the prices were rising, therefore support was needed, but this time from the government. They emphasized that after all, they were Austrian citizens and as such, they expected actual relief from the government. They never got a response. As there were no adequate means for their support in Hungary, they were transported to Austria via the already mentioned Uherské Hradiště. ${ }^{6}$

And so, a wave of spontaneous refugees had flooded Hungary. In the early November a few thousand refugees went on wagons or even on foot across the Carpathians to Bártfa (present day Bardejov in Slovakia). The Hungarian Ministry of Internal Affairs informed that on November 17, 1914, there were over 10,000 refugees in that town. Apart from the refugee burden, that poor area of Upper Hungary had to put up with a lot of military troops stationing there at the same time. ${ }^{7}$ The problems with food shortages and poor sanitary conditions undoubtedly made everyone's lives miserable, but most of all the Slovakian peasants', who had to find additional accommodation and food for the refugees. Some of the latter did not stay in the town but instead headed southwards, as a result of which about 50,000 refugees landed in Kassa (present day Košice in Slovakia). The city's mayor appealed to the railway authorities to take the exiles out of the city. ${ }^{8}$ Also western areas of Hungary saw an influx of refugees: for instance, in November 1914, over 2,500 Galicians found themselves in the Trencsén County, ${ }^{9}$ where it was planned to put altogether about 10,000 evacuees

3 Ilustrowany Kuryer Codzienny 1916, no. 171, June 23, p. 3.

4 ÖStA, Allgemeines Verwaltungsarchiv (in the following: AVA), Ministerium des Innern (in the following: MdI), Allgemeine (in the following: Allg.), Fasz. 19, Kt. 1921, Zl. 40164/1914.

5 ÖStA, AVA, MdI, Allg., Fasz. 19, Kt. 1921, Zl. 39414/1914; Budapesti Hirlap 1914, no. 238, September 27, p. 15.

6 ÖStA, AVA, MdI, Allg., Fasz. 19, Kt. 1922, Zl. 44571/1914.

7 ÖStA, AVA, MdI, Allg., Fasz. 19, Kt. 1922, Zl. 44239/1914.

8 ÖStA, AVA, MdI, Allg., Fasz. 19, Kt. 1921, Zl. 40075/1914.

9 Present day the area of the former county situated in Slovakia. 
from Cracow. ${ }^{10}$ It all stopped there and later transports were directed to Moravia and Bohemia. The reason for changing the direction was the uncompromising attitude of the Hungarian government regarding refugees but also their feeling of alienation due to the language barrier. The question of finances would return repeatedly in the talks between Vienna and Budapest and it was planned to be settled after the war. ${ }^{11}$

\section{THE REFUGEES' PLIGHT IN HUNGARY}

The situation of Galician refugees in Hungary was terrible. On January 9, the Minister for Internal Affairs in Vienna got a telegram saying that the evacuees, including young children, were dying of hunger there. The message was simply a cry for instant help. ${ }^{12}$ In addition, the exiles were perceived as aliens, and surely, one of the reasons why Hungarians were unkind to them, was the state finances: Budapest had hardly any intention of paying for the support of Galicians, i.e. Austrian citizens. In the Hungarian provinces the situation of war exiles was even more dramatic. For example, in the middle of April 1915, the mayor of the town of Kisújszállás situated in the Jász-Nagykun-Szolnok County, pointed out in a letter to the ispán (bailiff) that officially 400 refugees of Austrian citizenship had been registered there, whereas actually there were 785 of them, mainly railway workers with their families. That surplus was a burden to the town, whose residents were hungry themselves, while all flour supplies were allocated to the constantly arriving refugees. ${ }^{13}$ The letter to the authority was supposed to enforce some relief for the town, but at the same time it was an appeal to remove the Galician exiles.

Refugees were often helpless in the face of poverty and lack of understanding from the locals. The helplessness would sometimes make people write letters - requests on behalf of the Galician refugees to improve their situation or at least to understand them. Among the letter-writers there was a rabbi from Leżajsk, Chaskel Landau, who, on February 26, 1915, sent a letter from Újfehértó in Hungary to the Ministry of Internal Affairs in Vienna, through the agency of the Ministry of Internal Affairs in Budapest. Rabbi Landau wrote the letter on behalf of the 267 Galician refugees staying in Újfehértó, who had been in exile for over 5 months and who did not want to be a burden for the town any longer. He emphasized that those people had had money at the beginning but because the war had already lasted too long, all their provisions had run out and they were left penniless. The rabbi added that their poverty was indescribable; among them there were a lot of old people and sick children. Asking for support for them, the rabbi emphasized that "the situation of those

\footnotetext{
10 ÖStA, AVA, MdI, Allg., Fasz. 19, Kt. 1922, Zl. 44239/1914.

ÖStA, AVA, MdI, Allg., Fasz. 19, Kt. 1925, Zl. 3196/1915.

2 ÖStA, AVA, MdI, Allg., Fasz. 19, Kt. 1924, Zl. 895/1915.

13 MNL, JNSZML IV. 407. JNSZ Vármegye alispánjának iratai 1236/1915.
} 
poor people needed to be considered as a question of life or death." ${ }^{14}$ Similarly, in a letter sent to the Ministry of Internal Affairs in Vienna on April 21 1915, signed by the heads of 38 Galician refugee families in exile in Budapest, the letter read:

We are feeling here like in a foreign country, where the language is completely incomprehensible to us and where people are unfriendly towards us. We are uncomfortable and we are very bitter about what fate has prepared for us ... apart from the extremely hard living conditions, it is also very hard for us to satisfy our mental needs. ${ }^{15}$

It was not only alienation and lack of understanding that harassed the refugees. As they were still Austrian citizens, they were entitled to getting a daily allowance from the Austrian authorities. ${ }^{16}$ Still, there were complaints that in the case of the refugees staying in Hungary, the benefit was not paid out on time. It was only later that the situation improved and after the amount of the benefit had risen, following the directive of December 1, 1916, the payment was better controlled in Hungary, which the Ministry of Internal Affairs in Budapest had been advised to remember. ${ }^{17}$ Still, the situation was not favourable to war migrants. For example, in the town of Csepreg and the vicinity at the beginning of 1917 there were 140 Galician refugees, who had not received their due financial benefit since December 1916, until March 1917. ${ }^{18}$ They had therefore no money to buy basic food items, rent a flat or buy fuel to keep warm. What is more, all that was happening during the winter of 1916/1917. The situation in the provinces did not change radically over the course of a year. Next winter, 1917/1918, a letter came to the Ministry of Internal Affairs in Vienna from a refugee Josef Rottman who was living in a village of Bakonycsernye. He described the situation of refugees in December 1917, arguing that since October 15, they had not received any grain or flour and they were starving. They had only kept a coupon for potatoes and had not received any either. They had not had any new clothes for a year, some of them went barefoot, and it was winter. ${ }^{19}$ The same thing happened in spring 1918 in Bácsalmás, where the refugees were told in an unkind way by a local official that there was no money for Austrian refugees and no benefits would be paid until some means were sent from Vienna to Budapest. ${ }^{20}$ The struggle between a war exile and official bureaucracy was one for survival.

14 ÖStA, AVA, MdI, Allg., Kt. 1927, Zl. 9412/15.

15 ÖStA, AVA, MdI, Allg., Fasz. 19, Kt. 1930, Zl. 17741/1915.

16 Eligible for the benefit were only those refugees who were accommodated outside the barrack camps. At first it was 70 halers per person; during the war the benefit was raised due to uprating (since 1917 it was 1 krone daily per person. Krone (in Hungarian korona was the domestic currency until was changed to pengö on January 1, 1927). As a rule it was paid out officially as advance payment (e.g. 2-week one).

17 ÖStA, AVA, MdI, Allg., Fasz. 19, Kt. 1974, Zl. 1553/1917.

18 ÖStA, AVA, MdI, Allg., Fasz. 19, Kt. 1978, Zl. 12518/1917.

19 ÖStA, AVA, MdI, Allg., Fasz. 19, Kt. 2018, Zl. 80486/1917.

20 ÖStA, AVA, MdI, Allg., Fasz. 19, Kt. 2026, Zl. 23765/1918. 


\section{OUR FOLK OR ALIENS?}

Hungarians, especially those living in Budapest, very soon had had enough of Galicians, and did not really try to hide it. The Hungarian Ministry of Internal Affairs took different steps to limit the influx of refugees to Budapest. The financial benefits were used as a tool to make the Galicians leave the city. A list was compiled of those who had arrived in Budapest before January 15, 1915 and rented a flat or a room; on that basis they were paid out the allowance (at Austria's expense, of course). Whereas those who had arrived after January 15, 1915, could not hope for any financial support and what is more, were instantly sent to Cisleithania. ${ }^{21}$

The ultimate solution of the problem of Galician and Bukovinian refugees in Hungary came in the spring of 1915 . At first there were rumours, enhanced by the press, about expelling Austrian exiles from the Lands of the Crown of Saint Stephen. That must have been a result of behind-the-scenes information leaking out about an original plan: the Hungarian Ministry of Internal Affairs had been planning to move Galician refugees back to Austria by April 7, 1915. Those plans were suspended, however, which the Austrian Ministry of Internal Affairs in Vienna was informed about by phone. ${ }^{22}$ Further official orders concerning the ridding Hungary of Galician and Bukovinian refugees came on April 9 in the same year. One day later a meeting took place in the Budapest city hall, where the police head announced that all refugees, no matter whether they had any means to live on or not, were to leave Budapest. Because of Easter, the date of the forced removal was shifted to April 29. ${ }^{23}$ The usual most convincing argument was used, i.e. the payment of the refugee benefit. The agreement between the Hungarian and Austrian Ministries of Internal Affairs provided for withholding it on May 15. It was an absolute deadline by which the exiles had to leave Hungary. It was therefore demanded that all refugees reported to the Committee for Austrian Refugees' Relief which was situated in the VIII district (Csokonai utca (street) 6) between April 14 and 24 in order to establish the date of their departure to Austria. In the case of the people who did not report of their own free will in time, the date was fixed by the authorities. The Committee assured them that in different parts of Austria appropriate accommodation had already been secured. Moreover, it was also assured that the Jews would get kosher food, all refugees were promised access to religious service and a chance to get a job and any other relief from the Austrian government. Meanwhile rumours appeared in Budapest, distributed by Jewish newspaper Allgemeine jüdische Zeitung, that those directives had been cancelled. That caused some unrest among the interested parties but as it turned out, the information was not true and the refugee resettlement plan was carried out. ${ }^{24}$

The decision about having to leave was received with mixed feelings by the refugees. Some would have preferred to stay in Hungary, tired of the constant moving.

21 Budapesti Hirlap 1915, no. 16, January 16, p. 10.

22 ÖStA, AVA, MdI, Allg., Fasz. 19, Kt. 1929, Zl. 16180/1915.

23 Ilustrowany Kuryer Codzienny 1916, no. 171, June 23, p. 3.

24 ÖStA, AVA, MdI, Allg., Fasz. 19, Kt. 1929, Z1. 16180/1915; Pester Lloyd 1915, April 10, p. 9. 
Some circles, mainly those of rich Jews, were not eager to leave Budapest, arguing that outside a capital city they would have to live in group accommodation with poor hygienic conditions, together with the poor, with no access to proper (including kosher) food and appropriate religious service, ${ }^{25}$ which had theoretically been guaranteed to them before they left. Experience told them they had already been promised much more but were often deprived of many things essential for their existence. Some Jews decided to leave Hungary instantly, as the atmosphere they had been living in was unbearable to them. An example can be a large group of refugees who wrote in a letter to the Austrian Minister for Internal Affairs that they had received the news about leaving Hungary without surprise and with certain relief, because they had been feeling there like in a foreign country with an incomprehensible language and the local people did not hide their dislike towards them. Also the high cost of living was mentioned and the impossibility to satisfy the basic needs. They wrote that they hoped the conditions in Cisleithania would be better than the previous ones. They emphasized they belonged to the upper class Jews from Galicia. They did not want to end up in barrack camps they had heard stories about from the people coming to Budapest or from the press. The intention of their letter was then to ask to be accommodated in selected districts with their fellow believers. ${ }^{26}$ The fears of being relocated from Hungary to barrack camps were common among the refugees. For example, in the letter of April 18, 1915 of Chaim Salamon and Chaskel Herbstmann, written on behalf of 66 families from Gorlice and the region, staying in Budapest, the authors appealed to the Ministry of Internal Affairs to be granted a free transfer to selected places in the Moravian or Bohemian parts of the monarchy. At the end of the letter it was added that their request only referred to relocation to particular towns, "by no means (sic!) to any barrack camps." ${ }^{27}$ That fear was not only connected with the widely known facts about terrible living conditions but for some families also with the fact that in the camps people were placed regardless of their social background. As some refugees emphasized, afraid of being relocated from Hungary to Austria: "The terrible conditions in the barrack camps, where thousands of lower-class people were accommodated, would be for us, the superior and more intelligent group, unbearable." ${ }^{28}$ The forced return transports left much to be desired. Even deputies to the Vienna Parliament intervened about the matter, such as Adolf Gross, Natan Loewenstein, Henryk Kolischer, Ignacy Steinhaus and Edmund Rauch. The politicians received a lot of complaints from the resettled refugees. For example, during the transfer of refugees from Hungary to Austria and their relocation in Cisleithania, religious affiliation was not taken into account. In fact, Jewish people formed a very close-knit cultural and religious community. That was seen during evacuations as well as in exile, where one could find whole shtetls. The letter also appealed for a better organization of return transports, including securing a meal at the border station. Further, it was said that it would be advisable to enable refugees'

\footnotetext{
25 ÖStA, AVA, MdI, Allg., Fasz. 19, Kt. 1922, Zl. 44571/1914.

26 ÖStA, AVA, MdI, Allg., Fasz. 19, Kt. 1930, Zl. 17741/1915.

7 ÖStA, AVA, MdI, Allg., Fasz. 19, Kt. 1930, Zl. 19096/1915.

28 ÖStA, AVA, MdI, Allg., Fasz. 19, Kt. 1930, Zl. 17741/1915
} 
return to their homeland, and for the time of their stay in Austria, it was recommended to organize regular inspections led by a specially appointed rabbi, who would check the refugees' temporary lodgings in terms of quality and control whether the religious needs were met. ${ }^{29}$ The demand to be able to return to homeland was not possible to meet yet, because of the military and economic situation in Galicia.

In connection with the deteriorating provisions and above all, housing situation in Budapest, the Hungarian Ministry of Internal Affairs once again ordered resettlement of Austrian citizens from Hungary. The attempts to relocate people were carried out step by step; for instance, in April 1916, the Bohemian Governorship in Prague sent a letter to the Ministry of Internal Affairs in Vienna, informing it there was place in the districts of the crown land for three thousand refugees from Hungary. ${ }^{30}$ The number was not sufficient, though, to carry out the relocation of another wave of refugees, which after June 1916, turned out to be much larger.

\section{THE BRUSILOV OFFENSIVE AND ANOTHER WAVE OF REFUGEES}

The large-scale action of ridding Hungary of unwanted guests was run quite efficiently, however not all refugees left the Lands of the Crown of Saint Stephen. Moreover, after subsequent evacuations, like e.g. the Brusilov offensive in June 1916, there came other refugee waves, which did not bypass Hungary either. They were of a different scale and nature than the civilian migrations of 1914. As a consequence of warfare, in June 1916, the Lands of the Crown of Saint Stephen admitted masses of Galicians and Bukovinians (the latter to a much lesser extent). Unlike the first wave of refugees from the first stage of the war, the authorities decided to prepare for accommodating the civilians, making suitable plans. As a result, the Hungarian Ministry of Internal Affairs prepared documents for particular counties, according to which it was possible to accommodate altogether nearly 25,000 refugees. What is more, it was declared that more of them could be admitted in the case of further evacuations; that was, however, conditional on the demand and the movements of refugees towards the Hungarian border. Furthermore, at government level - in the Ministry of Internal Affairs - there were talks concerning possible accommodation options. Since there were no refugee camps in Hungary (unlike Austria, where special camps were organized to that end), a suggestion was put forward to make an agreement with the military administration and take over one of the unused POW camps. Admittedly, it was argued that the refugees would remain in their local groups and would not get dispersed, however, placing civilians who had fled the ravages of war in a POW camp could have evoked negative connotations. Along with the plans to distribute the evacuees, the Austrian government declared that as of August 1, 1916, there would be no civilian transports to Hungary, except for

\footnotetext{
29 ÖStA, AVA, MdI, Allg., Fasz. 19, Kt. 1947, Z1. 61046/1915.
}

30 ÖStA, AVA, MdI, Allg., Fasz. 19, Kt. 1956, Z1. 15686/1915. 
unforeseen emergency evacuations. The refugees who would land in Hungary, not only directly from Galicia, but also with the transports from Austria (i.e. the control station in Uherské Hradiště (present day this city is located in the Czech Republic), were going to remain in the same districts so that given groups of people were not separated. It was also assured that the refugees, as citizens of the Austrian part of the Habsburg monarchy, would be paid an allowance of 1 krone daily per person, which was going to be reimbursed later by the Austrian government. ${ }^{31}$

Table 1: Distribution of Galician Refugees after Brusilov Offensive in Hungary (general)

\begin{tabular}{|l|c|}
\hline \multicolumn{1}{|c|}{ County } & Number of refugees \\
\hline Trencsén & $\mathbf{3 , 0 0 0}$ \\
\hline Nyitra & $\mathbf{4 , 0 0 0}$ \\
\hline Pozsony & $\mathbf{2 , 3 5 0}$ \\
\hline Sopron & $\mathbf{4 , 0 0 0}$ \\
\hline Vas & $\mathbf{2 , 5 0 0}$ \\
\hline Veszprém & $\mathbf{4 , 0 0 0}$ \\
\hline Fejér & $\mathbf{3 , 1 3 0}$ \\
\hline Györ & $\mathbf{2 , 0 0 0}$ \\
\hline & $\mathbf{2 4 , 9 8 0}$ \\
\hline
\end{tabular}

(Source: ÖStA, AVA, MdI, Allg., Fasz. 19, Kt. 1964, Zl. 37115/1916)

Table 2: Distribution of Galician Refugees after Brusilov Offensive in Trencsén County

\begin{tabular}{|l|c|l|}
\hline \multicolumn{1}{|c|}{ Settlement (city/town) / district } & Number of refugees & \multicolumn{1}{c|}{ Railway station } \\
\hline Zsolna (city) & 300 & Zsolna \\
\hline Trencsén (city) & 200 & Trencsén \\
\hline Zsolna (district) & 300 & Zsolna \\
\hline Nagybiccse & 300 & Nagybiccse \\
\hline Vágbeszterce & 300 & Vágbeszterce \\
\hline Puhó & 300 & Puhó \\
\hline Illava & 300 & Illava \\
\hline Trencsén (district) & 300 & Trencsén \\
\hline Ban & 300 & Ban \\
\hline Csaca & 250 & Csaca \\
\hline Kisuczaujhely & 150 & Kisuczaujhely \\
\hline Total number (Trencsén County) & & $\mathbf{3 , 0 0 0}$ \\
\hline
\end{tabular}

(Source: ÖStA, AVA, MdI, Allg., Fasz. 19, Kt. 1964, Zl. 37115/1916)

31 ÖStA, AVA, MdI, Allg., Fasz. 19, Kt. 1964, Z1. 37115/1916. 
Table 3: Distribution of Galician Refugees after Brusilov Offensive in Nyitra County

\begin{tabular}{|c|c|c|}
\hline Settlement (city/town) / district & Number of refu gees & Railway station \\
\hline Ersekújvár (city) & 400 & Ersekújvár \\
\hline Ersekújvár (district) & 400 & Nagysurány \\
\hline Nagytapolcsány & 300 & Nagytapolcsány \\
\hline Szakolca (district) & 400 & Holics \\
\hline Szakolca (city) & 250 & Szakolca \\
\hline Privigye & 150 & Privigye \\
\hline Galgócz & 700 & Galgócz \\
\hline Nyitra (city) & 400 & Nyitra \\
\hline Vágújhely (city) & 500 & Vágujhely \\
\hline Vágújhely (district) & 500 & Verbó \\
\hline Total number (Nyitra County) & \multicolumn{2}{|c|}{} \\
\hline
\end{tabular}

(Source: ÖStA, AVA, MdI, Allg., Fasz. 19, Kt. 1964, Zl. 37115/1916)

Table 4: Distribution of Galician Refugees after Brusilov Offensive in Pozsony County

\begin{tabular}{|l|c|l|}
\hline Settlement (city/town) / district & Number of refugees & Railway station \\
\hline Dunaszerdahely & 350 & Dunaszerdahely \\
\hline Somorja & 300 & Somorja \\
\hline Galánta & 200 & Galánta \\
\hline Nagyszombat (district) & 400 & Nagyszombat \\
\hline Szencz & 150 & Szencz \\
\hline Pozsony & 250 & Pozsony \\
\hline Malaczka & 250 & Malaczka \\
\hline Nagyszombat (city) & 200 & Nagyszombat \\
\hline Modor (city) & 100 & Modor \\
\hline Bazin (city) & 100 & Bazin \\
\hline Szentgyörgy (city) & 50 & Szentgyörgy \\
\hline Total number (Pozsony County) & $\mathbf{2 , 3 5 0}$ \\
\hline
\end{tabular}

(Source: ÖStA, AVA, MdI, Allg., Fasz. 19, Kt. 1964, Zl. 37115/1916)

Table 5: Distribution of Galician Refugees after Brusilov Offensive in Sopron County

\begin{tabular}{|l|c|l|}
\hline Settlement (city/town) / district & Number of refugees & Railway station \\
\hline Sopron (city) & 40 & Sopron \\
\hline Csepreg & 600 & Csepreg \\
\hline Csorna & 600 & Csorna \\
\hline Felsőpulya & 600 & Felsőpulya \\
\hline Kismarton & 600 & Kismarton \\
\hline
\end{tabular}




\begin{tabular}{|l|c|l|}
\hline Kapuvár & 600 & Kapuvár-Garta \\
\hline Sopron & 600 & Sopron \\
\hline Nagymarton & 300 & Nagymarton \\
\hline Kismarton (city) & 30 & Kismarton \\
\hline Ruszt (city) & 30 & Ruszt \\
\hline Total number (Sopron County) & \multicolumn{2}{|c|}{$\mathbf{4 0 0}$} \\
\hline
\end{tabular}

(Source: ÖStA, AVA, MdI, Allg., Fasz. 19, Kt. 1964, Zl. 37115/1916)

Table 6: Distribution of Galician Refugees after Brusilov Offensive in Vas County

\begin{tabular}{|l|c|l|}
\hline Settlement (city/town) / district & Number of refugees & Railway station \\
\hline Szombathely & 320 & Szombathely \\
\hline Sárvár & 280 & Sárvár \\
\hline Czelldömölk & 320 & Czelldömölk \\
\hline Vasvár & 200 & Vasvár \\
\hline Körmend & 200 & Körmend \\
\hline Szentgotthárd & 300 & Szentgotthárd \\
\hline Németújvár & 300 & Németújvár \\
\hline Felsőőr & 300 & Felsőőr \\
\hline Köszeg & 70 & Rohoncz \\
\hline Felsőőr & 30 & Tarcsafürdő \\
\hline Köszeg & 80 & Köszeg \\
\hline Köszeg (city) & 100 & Köszeg \\
\hline Total number (Vas County) & $\mathbf{2 , 5 0 0}$ \\
\hline
\end{tabular}

(Source: ÖStA, AVA, MdI, Allg., Fasz. 19, Kt. 1964, Zl. 37115/1916)

Table 7: Distribution of Galician Refugees after Brusilov Offensive in Veszprém County

\begin{tabular}{|l|c|l|}
\hline \multicolumn{1}{|c|}{ Settlement (city/town) / district } & Number of refugees & \multicolumn{1}{c|}{ Railway station } \\
\hline Veszprém (city) & 250 & Veszprém \\
\hline Pápa (city) & 250 & Pápa \\
\hline Pápa (district) & 800 & Pápa \\
\hline Enying & 800 & Enying \\
\hline Devecser & 700 & Devecser \\
\hline Zircz & 600 & Zircz \\
\hline Veszprém & 600 & Veszprém \\
\hline Total number (Veszprém County) & $\mathbf{4 , 0 0 0}$ \\
\hline
\end{tabular}

(Source: ÖStA, AVA, MdI, Allg., Fasz. 19, Kt. 1964, Zl. 37115/1916) 
Table 8: Distribution of Galician Refugees after Brusilov Offensive in Fejér County

\begin{tabular}{|l|c|l|}
\hline Settlement (city/town) / district & Number of refugees & Railway station \\
\hline Mór & 400 & Mór \\
\hline Székesfehérvár & 750 & Székesfehérvár \\
\hline Sárbogárd & 600 & Sárbogárd \\
\hline Vál & 750 & Baracska \\
\hline Adony & 127 & Adony \\
\hline Adony & 121 & Ercsi \\
\hline Adony & 72 & Érd \\
\hline Adony & 174 & Pusztaszabolcs \\
\hline Adony & 54 & Ráczalmás \\
\hline Adony & 82 & Dunapentele \\
\hline Total number (Sopron County) & $\mathbf{3 , 1 3 0}$ \\
\hline
\end{tabular}

(Source: ÖStA, AVA, MdI, Allg., Fasz. 19, Kt. 1964, Zl. 37115/1916)

Table 9: Distribution of Galician Refugees after Brusilov Offensive in Györ County

\begin{tabular}{|l|l|c|l|}
\hline \multicolumn{1}{|c|}{ District } & \multicolumn{1}{|c|}{$\begin{array}{c}\text { Settlement } \\
\text { (town/village) }\end{array}$} & Number of refugees & Railway station \\
\hline Tósziget-Csilizköz & Abda & 20 & Abda \\
\hline Tósziget-Csilizköz & Börcs & 10 & Abda \\
\hline Tósziget-Csilizköz & Pinnyéd & 10 & Györ \\
\hline Tósziget-Csilizköz & Ballony & 15 & Nagymegyer \\
\hline Tósziget-Csilizköz & Medve & 15 & Nagymegyer \\
\hline Tósziget-Csilizköz & Csiliznyárad & 15 & Nagymegyer \\
\hline Tósziget-Csilizköz & Szap & 15 & Nagymegyer \\
\hline Tósziget-Csilizköz & Bácsa & 25 & Györ \\
\hline Tósziget-Csilizköz & Alsóvámos & 15 & Györ \\
\hline Tósziget-Csilizköz & Győrszabadi & 10 & Györ \\
\hline Tósziget-Csilizköz & Csilizradvány & 20 & Nagymegyer \\
\hline Tósziget-Csilizköz & Kulcsod & 15 & Nagymegyer \\
\hline Tósziget-Csilizköz & Cisilizpatas & 15 & Nagymegyer \\
\hline Tósziget-Csilizköz & Gönyü & 40 & Nagyszentjános \\
\hline Tósziget-Csilizköz & Győrszentiván & 70 & Györszentiván \\
\hline Tósziget-Csilizköz & Györzámoly & 30 & Györ \\
\hline Tósziget-Csilizköz & Győrújfalu & 15 & Györ \\
\hline Tósziget-Csilizköz & Győrladamér & 10 & Györ \\
\hline Tósziget-Csilizköz & Dunaszeg & Györ \\
\hline Tósziget-Csilizköz & Dunaszentpál & & Györ \\
\hline
\end{tabular}




\begin{tabular}{|c|c|c|c|}
\hline Tósziget-Csilizköz & Győrsövényház & 25 & Enese \\
\hline Tósziget-Csilizköz & Bezi & 20 & Enese \\
\hline Tósziget-Csilizköz & Fehértó & 15 & Enese \\
\hline Tósziget-Csilizköz & Kóny & 40 & Kóny \\
\hline Tósziget-Csilizköz & Kisbajcs & 10 & Győr \\
\hline Tósziget-Csilizköz & Nagybajcs & 15 & Győr \\
\hline Tósziget-Csilizköz & Szőgye & 5 & Győr \\
\hline Tósziget-Csilizköz & Vének & 10 & Győr \\
\hline Tósziget-Csilizköz & Markotabödöge & 20 & Kóny \\
\hline Tósziget-Csilizköz & Tárnokréti & 15 & Bősárkány \\
\hline Tósziget-Csilizköz & Rábczakapi & 10 & Bősárkány \\
\hline Tósziget-Csilizköz & Czakóháza & 5 & Kóny \\
\hline Tósziget-Csilizköz & Öttevény & 40 & Öttevény \\
\hline Tósziget-Csilizköz & Kunsziget & 40 & Öttevény \\
\hline Tósziget-Csilizköz & Rábapatona & 30 & Enese \\
\hline Tósziget-Csilizköz & Ikrény-pta & 10 & Ikrény-pta \\
\hline Tósziget-Csilizköz & Enese & 20 & Enese \\
\hline Tósziget-Csilizköz & Ráró & 20 & Horvátkimle \\
\hline Tósziget-Csilizköz & Ásvány & 30 & Horvátkimle \\
\hline Tósziget-Csilizköz & Hédervár & 20 & Horvátkimle \\
\hline $\begin{array}{l}\text { Total number } \\
\text { (Tósziget-Csilizköz) }\end{array}$ & \multicolumn{3}{|c|}{800} \\
\hline Sokoróalja & $\begin{array}{l}\text { Csanakfalu } \\
\text { Csanakhegy } \\
\text { Ménfó }\end{array}$ & 50 & Ménfö \\
\hline Sokoróalja & $\begin{array}{l}\text { Koronczó } \\
\text { Gyirmót }\end{array}$ & 50 & Ménfö \\
\hline Sokoróalja & $\begin{array}{l}\text { Tényőfalu } \\
\text { Tényőhegy } \\
\text { Sokorópátka }\end{array}$ & 60 & Győrszemere \\
\hline Sokoróalja & Győrszemere & 40 & Győrszemere \\
\hline Sokoróalja & Felpécz & 30 & Felpéczhali \\
\hline Sokoróalja & Tét & 60 & Gyömöre \\
\hline Sokoróalja & Kajár & 30 & Gyömöre \\
\hline Sokoróalja & Kispécz & 20 & Gyömöre \\
\hline Sokoróalja & $\begin{array}{l}\text { Gyömöre } \\
\text { Szerecsen }\end{array}$ & 60 & Gyömöre \\
\hline
\end{tabular}




\begin{tabular}{|c|c|c|c|}
\hline Sokoróalja & $\begin{array}{l}\text { Nagymórichida } \\
\text { Kisórichida }\end{array}$ & 50 & Gyömöre \\
\hline Sokoróalja & Gyarmat & 40 & Gyarmat \\
\hline Sokoróalja & Csikvánd & 30 & Csikvánd \\
\hline Sokoróalja & $\begin{array}{l}\text { Újmalomsok } \\
\text { Ómalomsok }\end{array}$ & 30 & Gyarmat \\
\hline Sokoróalja & $\begin{array}{l}\text { Rábacsécsény } \\
\text { Rábaszentmihály } \\
\text { Mérges } \\
\text { Kisbabot }\end{array}$ & 50 & Enese \\
\hline $\begin{array}{l}\text { Total number } \\
\text { (Sokoróalja) }\end{array}$ & \multicolumn{3}{|c|}{600} \\
\hline Puszta & $\begin{array}{l}\text { Nyúlfalu } \\
\text { Nyúlhegy }\end{array}$ & 50 & Nyúl \\
\hline Puszta & $\begin{array}{l}\text { Nagyécsfalu } \\
\text { Nagyécshegy }\end{array}$ & 40 & Nagyécs \\
\hline Puszta & Győrszentmárton & 60 & Győrszentmárton \\
\hline Puszta & $\begin{array}{l}\text { Pázmándfalu } \\
\text { Pázmándhegy }\end{array}$ & 20 & Győrszentmárton \\
\hline Puszta & Győrság & 30 & Györszentmárton \\
\hline Puszta & Nyalka & 20 & Győrszentmárton \\
\hline Puszta & Ravazd & 40 & Ravazd \\
\hline Puszta & Győrasszonyfa & 30 & Győrasszonyfa \\
\hline Puszta & Tápszentmiklós & 30 & Tápszentmiklós \\
\hline Puszta & Táp & 50 & Győrasszonyfa \\
\hline Puszta & Mezöörs & 50 & Győrasszonyfa \\
\hline Puszta & Nagybarátfalu & 40 & Csanak \\
\hline Puszta & Kisbarátfalu & 40 & Csanak \\
\hline Puszta & Bónyrétalap & 50 & Nagyszentjános \\
\hline Puszta & Pér & 50 & Győrasszonyfa \\
\hline $\begin{array}{l}\text { Total number } \\
\text { (Puszta) }\end{array}$ & \multicolumn{3}{|c|}{600} \\
\hline $\begin{array}{l}\text { Total number } \\
\text { (Győr County) }\end{array}$ & \multicolumn{3}{|c|}{2,000} \\
\hline
\end{tabular}

(Source: ÖStA, AVA, MdI, Allg., Fasz. 19, Kt. 1964, Zl. 37115/1916) 
Until the end of the war Galicians were to be seen in Budapest and some other Hungarian cities. In June 1916, the press reported that in the capital alone there were 10,000 Galician exiles, still treated as intruders..$^{32}$ Further transports of Austrian civilian refugees were unavoidable. They were announced to take place on September 18, 1916. It was argued that on the one hand Hungary had to be prepared for a possible evacuation of Transylvania, on the other hand, it was reported that Hungary did not have any special refugee camps and the area was not economically prepared to accommodate large groups of outlanders. Nevertheless, the Austrian part of the monarchy was not ready to handle such a big transfer of people, either. The reason was that refugees had already been accommodated in camps and in particular districts all over Cisleithania. All that contributed to the tension between the Ministries of Internal Affairs in Budapest and in Vienna. Budapest pressed Vienna to accept over 25,000 refugees in a short period of time, to which Vienna replied it was not possible. The Hungarians said the same, arguing that their government had already taken care of over half a million (up to 600,000 ) refugees. ${ }^{33}$ The debates between the ministries in Vienna and Budapest continued. Despite relocations and earlier transports from Hungary to Austria, in the early 1917 there were still 16-18,000 Galician refugees in western Hungary. ${ }^{34}$ They were still a burden for Hungary, hence the question returned, how to remove them. The argument in favour was vacating room for the evacuees from Transylvania after Romania joined the war on the side of the Entente in August 1916. As a result, the refugee transfers scheduled for September 1917, were carried out. ${ }^{35}$

\section{THE LAST YEAR OF THE WAR AND THE PROBLEM WITH THE REFUGEES}

Basically, war exile was supposed to be temporary: after the end of the hostilities people were to return to their homes. Yet, the return was complicated, which depended not only on the warfare itself, but also on the economic situation in the area to return to. People started getting back home already in the summer of 1915; that lasted gradually until the end of the war but had not been completed by then. ${ }^{36}$ The question also concerned the refugees staying in Hungary for the war. Some people would return on their own, for example those who had been staying in Trencsén (Present day Trenčin in Slovakia) until July 16, left the town for Galicia. Some, however, did

32 Ilustrowany Kuryer Codzienny 1916, no. 171, June 23, p. 3.

33 ÖStA, AVA, MdI, Allg., Fasz. 19, Kt. 1967, Zl. 48456/1916.

34 ÖStA, AVA, MdI, Allg., Fasz. 19, Kt. 1978, Zl. 12474/1917.

35 Ilustrowany Kuryer Codzienny 1917, no. 244, September 4, p. 4.

36 For more on that cf. K. Ruszała, "Galicyjscy uchodźcy w Austro-Węgrzech w trakcie pierwszej wojny światowej” [in:] Wielki Przełom. Konflikty zbrojne i przemiany wojskowości 1912-1923, ed. M. Baczkowski, Kraków 2018, p. 107-121. 
not see a chance for returning, because of the already mentioned economic situation in the country. In September 1918, Josef Meier Plessner sent a letter to the Central Office for War Refugees on his own behalf and on behalf of the refugees staying in Szápár. In the letter he wrote:

On August 15, we were ready to leave for Galicia, but we were not taken. The departure was delayed because of the holiday. Meanwhile, some of us went to Galicia. They say it is a povertystricken area. There is nowhere to live; they were told in the district office to get back to where they came from. ... Therefore, we would like to know what to do. Should we spend the winter in Hungary or return to Galicia? . . Please note that most of us are women with young children and a group of elderly people. We have no clothes or shoes and winter is coming. Since August 15, we have not been getting any money [benefits - K.R.] and since August 5, we have not received any flour. If we want to buy flour on our own, we find out we are strictly forbidden to do it. But we are easily allowed to die of hunger. ${ }^{37}$

The disgruntlement of residents in the areas now inhabited by refugees was growing with the lingering warfare. To make matters worse, there came military defeats, resulting in many losses in the army, in which relatives of all citizens of the monarchy fought, including those of the refugees. The residents had enough of the whole situation and most of all, of the strangers, whom they accused of bad living conditions, rising prices and food shortages. At the turn of 1917 and 1918 the Ministry of Internal Affairs in Budapest reminded the "Austrian refugees" of the necessity to leave the Lands of the Crown of Saint Stephen..$^{38}$ Actually, since the beginning of 1918 Galician Jews were ruthlessly thrown out of the Hungarian capital there. The Az Est newspaper described how that was done. It reported that there were 25,000 people "in kaftans" in the town, which was a pejorative term for the gabardines they wore, an equivalent of the Austrian Kaftanjuden. In the early 1918 police would throw them out of their rented flats, often beds, by force. The newspaper described a story of a Galician rabbi Katz who had barred the door to his flat against Hungarian gendarmes. A locksmith was brought along, the door was opened, and the rabbi was thrown out of the flat. In order to persuade the public that removing refugees from Budapest was the right thing to do, the press wrote about the terrible sanitary conditions in the flats they were renting, adding that such stinking flats were not to be found anywhere else in Europe. ${ }^{39}$ It was not only in the capital of Transleithania, but also in the provinces that steps were taken to expel the refugees. On May 16, 1918 in Érsekújvár (present day Nové Zámky in Slovakia), the mayor, Aladár Miklóska, made an announcement in which he called on Galician refugees to leave the town in

37 ÖStA, AVA, MdI, Allg., Fasz. 19, Kt. 2026, Zl. 58129/1918 (translated from the German-language original by K.R.).

38 Cf. R. Nemes, "Refugees and Antisemitism in Hungary During the First World War" [in:] Sites of European Antisemitism in the Age of Mass Politics, 1880-1918, eds. H. Kieval, D. Unowsku, R. Nemes, Waltham, Mass. 2014, p. 254.

39 Ilustrowany Kuryer Codzienny 1918, no. 143, August 28, p. 3. 
8 days. As the reason for his decision he gave terrible food shortages and housing problems. ${ }^{40}$

There were some refugees who had no intention of getting back to Galicia, as they sought a better life. Sometimes economic emigrants mingled with the refugees or tried to pass themselves off as war exiles. An article appeared in a Budapest newspaper, titled "Nő a galiciai bevándorlás. Budapesten szabad megtelepedni," ${ }^{11}$ discussing the situation when day after day more refugees came to Budapest at the end of the war, while in fact they were emigrants seeking a better future in the Hungarian capital.

\section{CONCLUSION}

It would have seemed that crossing the Carpathian Mountains gave the fleeing Galicians at least some temporary rest from the war threat. The natural border was supposed to protect them against the enemy, but, as it turned out, it did not defend them from the hardships of living in the Lands of the Crown of Saint Stephen. In fact, it was similar in Budapest: though the city had remained in the shadow of Vienna, before the FWW it was a metropolis and a symbol of Hungarian prosperity. The Hungarians were proud of it and, just like in Vienna, the sight of Galician refugees, particularly Jews, did not fit in with the corso in the Pest part of the city or other major streets. Yet the most important role was played by economic factors, since indeed, there were no grounds for maintaining the "aliens" in the economically difficult period.

Hungarians showed an explicitly negative attitude towards the war migrants from Galicia. That was caused by a few factors. One of them were the stereotypes attributed to the outlanders, in particular the Jews from Galicia. They did not find a common language with the Hungarian Jews, who apparently felt a stronger bond with Hungary, their homeland, than with their religious community. Despite the shared religion, there was more that divided them. Moreover, Hungarians feared anti-Semitic feeling in their country, which could grow with the refugees staying there, as it happened in the Austrian part of the monarchy. Besides, the hardships of the war made refugees - again, just like in the Austrian part - competitors to the locals' supplies and provisions. The government decisions and the actions of expelling Austrian refugees from Hungary under pretence of their different national status, strengthened the feeling that in the Habsburg Monarchy they were connected only with Cisleithania and were just one of its parts. They remained strangers in Hungary, but they did not feel

40 ÖStA, AVA, MdI, Allg., Fasz. 19, Kt. 2026, Zl. 30139/1918. Cf. R. Nemes, Refugees and Antisemitism in Hungary, p. 236. See also: K. Ruszała, "Unwelcome guests": Situation of Galician Refugees in Austro-Hungary in 1918 (in press).

41 (The Galician immigration increases. To settle down in Budapest is allowed. - K.R.) Budapesti Hírlap 1918, no. 203, August 31, p. 5. 
too well in Austria either. This clearly shows the increasing "ethnicization" of the monarchy on the eve of its demise in 1918, intensified by war hardships and everyday struggle for survival.

\section{BIBLIOGRAPHY}

\section{Primary Sources}

Österreichisches Staatsarchiv (ÖStA), Kriegsarchiv (KA), Zentralstelle, Kriegsministerium, HR, Abt. 10, Karton (Kt.) 516.

ÖStA, Allgemeines Verwaltungsarchiv (AVA), Ministerium des Innern (MdI), Allgemeine (Allg.), Fasz. 19, Kt. 1921, 1922, 1924, 1925, 1929, 1930, 1956, 1964, 1967, 1974, 1978, 2018, 2026.

Magyar Nemzeti Levéltár Jász-Nagykun-Szolnok Megyei Levéltára, IV. 407. JNSZ Vármegye alispánjának iratai 1236/1915.

Budapesti Hirlap 1914, 1915, 1918.

Ilustrowany Kuryer Codzienny 1916, 1917, 1918.

Pester Lloyd 1915.

\section{Literature}

Gatrell P., A Whole Empire Walking: Refugees in Russia During World War I, Indianapolis 2005.

Gatrell P., The Making of the Modern Refugee, Oxford 2013.

Gatrell P., Zhvanko L. (eds.), Europe on the Move: Refugees in the Era of the Great War, Manchester 2017.

Mentzel W., Kriegsflüchtlinge in Cisleithanien im Ersten Weltkreg, Wien 1997 (unpublished, manuscript gatheted in Bibliothek des Institutes für Zeitgeschichte der Universität Wien).

Nemes R., "Refugees and Antisemitism in Hungary During the First World War" [in:] Sites of European Antisemitism in the Age of Mass Politics, 1880-1918, eds. H. Kieval, D. Unowsku, R. Nemes, Waltham, Mass. 2014.

Ruszała K., "Galicyjscy uchodźcy w Austro-Węgrzech w trakcie pierwszej wojny światowej” [in:] Wielki Przetom. Konflikty zbrojne i przemiany wojskowości 1912-1923, ed. M. Baczkowski, Kraków 2018, pp. 107-121.

Ruszała K., "Intellectuals and the Galician Refugees During World War I in Austria-Hungary: Disparate Attitudes" [in:] Intellectuals and World War I. A Central European Perspective, eds. T. Pudłocki, K. Ruszała, Kraków 2018.

Ruszała K., "Unwelcome guests": Situation of Galician Refugees in Austro-Hungary in 1918 (in press). 